\title{
AComparative Study of the Ameliorative Effect of Doxorubicin with Vitamin E versus Liposomal Doxorubicin on the Left Ventricular Original Histological and Immunohisochemical Changes Induced by
Article
}

\author{
Fadya K. Aly Abdu, Fayza E. Ahmad, Mohamed A. G. Shahin and Samar A. M. Yousef
}

Department of Histology and Cell Biology, Faculty of Medicine, Zagazig University

\begin{abstract}
Background and Aim: The use of Doxorubicin (Dox) to treat various tumors is limited by its cardiotoxicity. This study aimed to compare the cardioprotective potential of vitamin E versus liposomal-Dox against cardiotoxic effects on the structure of left ventricle.

Materials and Methods: Fifty male albino Wistar rats (180-220g) were divided into control (I), Dox (II), vitamin E with Dox (III) and liposomal-Dox (IV) groups. Groups II, III and IV received Dox and liposomal-Dox (3mg/kg) at days 1, 3, 5, 7, 9 and 11. Group III received Vitamin E $(100 \mathrm{mg} / \mathrm{kg})$ daily with Dox administration. At day 12, blood was collected and left ventricles were dissected and prepared for LM and EM study.

Results: Serum lactate dehydrogenase, creatine phosphokinase and creatine kinase-MB increased by 2.5 folds in Doxtreated rats compared to control rats, but decreased in vitamin E and liposomal-Dox groups compared to Dox group. The maximal decrease was in liposomal-Dox group with values near to control. LM examination of left ventricle from Doxgroup showed hemorrhagic areas between widely separated cardiomyocytes containing pyknotic nuclei. Inflammatory cells and adipocytes were seen in the interstitium. EM of Dox group showed variable sized mitochondria with ruptured cristae inbetween fragmented myofibrils. LM and EM examination of ventricles from vitamin E and liposomal-Dox groups showed mild changes with liposomal-Dox group appeared near to control. Left ventricular fiber diameter was decreased in Dox group compared to control group with nearly normal diameter in liposomal-Dox group. Area percent of collagen fibers increased and the optical density of desmin immune-expression was reduced in Dox group compared to control and liposomal-Dox groups which were alike.

Conclusion: Dox-induced structural changes of rat ventricle were diminished by concomitant vitamin E intake. LiposomalDox administration-only- was more effective in reducing these changes; hence, it can accomplish a successful clinical target to decrease Dox-associated cardiotoxicity.
\end{abstract}

Received: 04 January 2019, Accepted: 08 Feburary 2019

Key Words: Cardiotoxicity, doxorubicin, histology, liposomal-Dox, vitamin E.

Corresponding Author: Mohamed A. Shaheen, MD, Department of Histology and Cell Biology, Faculty of Medicine, Zagazig University, Zagazig, 44519, Egypt, Tel.: +20 1211613544, E-mail: drmohamedshaheen@yahoo.com

ISSN: 1110-0559, Vol. 42, No. 2

\section{INTRODUCTION}

Doxorubicin (Dox) is one of the anthracyclines which are a group of antibiotics that are among the most active chemotherapeutic agents. It is highly effective against a spectrum of malignancies including both hematological and solid tumors including lymphoma, gastric cancer, small cell lung cancer, sarcoma, and breast cancer ${ }^{[1]}$.

The pathogenesis of Dox-induced cardiotoxicity and heart failure is complex and may involve various signaling mechanisms including free radical stress, calcium overloading, dysregulation of iron homeostasis ${ }^{[2]}$, alteration in beta-adrenergic receptor signaling ${ }^{[3]}$, mitochondrial dysfunction ${ }^{[4]}$ and activation of matrix metalloproteinase ${ }^{[5]}$.

Multiple strategies are clinically used for early detection of anthracycline-induced cardiomyopathy. These include the measurement of serum cardiac enzymes e.g
LDH, CPK and CPK-MB that are closely associated with the severity of myocardial damage in patients treated with Dox or other chemotherapy ${ }^{[6]}$.

The free radicals and other toxic non-radicals generated by Dox can be neutralized by increasing endogenous antioxidants or by introducing exogenous antioxidants through nutritional supplements. These interventions may prevent or attenuate its side-effects without interfering with Dox activity in tumor cells $s^{[7]}$.

Sindhi et al. (2013) classified the antioxidants into three lines: The first line includes antioxidants that prevent the formation of new free radicals such as ferritin and $\mathrm{Zn}$. The second group of antioxidants is responsible for capturing free radicals such as vitamins ( $\mathrm{C}$ and $\mathrm{E})$, carotenoids and flavonoids. The third line of defense includes antioxidant enzymes that repair the damage caused by free radicals such as lipases and proteases $^{[8]}$. 
Nanotechnology as an emerging technology has been widely used in many fields and also to provide a better opportunity for the targeted delivery of cancer drugs ${ }^{[9]}$. One of the most successful nanotechnology intervention to decrease Dox associated cardiotoxicity is its encapsulation by a liposomal membrane (apolyethylene glycol-coated lipid membrane with a vesicle size of $80-90 \mathrm{~nm}$ ) which remains associated with Dox in the circulation with little free drug. Liposomal Dox is the first food and drug administration (FDA)-approved nano-drug (1995), is based on unrelated principles including : (i) prolonged drug circulation time and avoidance of the reticuloendothelial system due to the use of PEGylated nano-liposomes; (ii) high and stable remote loading of Dox driven by a transmembrane ammonium sulfate gradient, which also allows for drug release at the tumor ${ }^{[10]}$.

Therefore, the objective of this experimental study was to compare the cardio-protective potential of vitamin $\mathrm{E}$ versus liposomal Dox against Dox cardiotoxic effect using cardiac serum enzymes levels and the histological structure and desmin immunohistochemical reaction as paramerters of cardiac affection.

\section{MATERIALS AND METHODS}

\subsection{Drugs}

- Dox: vials; each contained $10 \mathrm{mg}$ in the form of powder,obtained from (Pfizer-Egypt).

- Vitamin E (tocopherol acetate): soft gelatinous capsules each containing $400 \mathrm{mg}$ supplied from (Pharco- Egypt).

- Liposomal Dox: vials containing suspension $20 \mathrm{mg}$ in $10 \mathrm{ml}(2 \mathrm{mg} / \mathrm{ml})$ from (Janssen,United kingdom).

\subsection{Experimental animals}

Fifty male wistar rats aged 3-4 months, weighing 180220 g, purchased from Animal House, Zagazig University were used in this study. They were housed in polypropylene cages under a 12-hour light/dark cycle at around $24 \pm 2 \mathrm{C}$. Rats were acclimatized to water and standard pellet. The experimental protocol was approved by the Institutional Animal Ethics Committee in Zagazig University.

\subsection{Experimental design and protocol}

- After acclimatization to the laboratory for two weeks, the animals were randomly divided into 4 groups:

Group I (control group): Twenty rats were divided into 2 equal groups (10 rats each):

- Subgroup Ia:

Rats received $0.9 \%$ sodium chloride $(\mathrm{NaCl})(1 \mathrm{ml} / 5$ rats).

-Subgroup Ib: Rats were given vitamin $\mathrm{E}$ at a dose of $100 \mathrm{mg} / \mathrm{kg} / \mathrm{B}$.W/daily for 12 days. Each capsule of vitamin E (400mg) was evacuated in corn oil (4ml). Each rat received $0.2 \mathrm{ml}$ daily given by gastric tube.
Group II (Dox-treated group): Ten rats were injected I.V with Dox at a dose $3 \mathrm{mg} / \mathrm{kg}$ BW at days $1,3,5,7,9$ and 11. Dox was obtained as a powder. Each vial $(10 \mathrm{mg})$ was dissolved in $3 \mathrm{ml} \mathrm{0.9 \%}$ sodium chloride and kept frozen until use. Each ml (containd 3 mg Dox / 5 rats) ${ }^{[11]}$.

Group III (vitamin E and Dox-treated group): The day before Dox administration, rats were given vitamin E (as subgroup Ib) with Dox administration (as group II) ${ }^{[12]}$.

Group (IV): (Liposomal Dox- treated group): Ten rats were injected with I.V liposomal Dox $3 \mathrm{mg} / \mathrm{kg} \mathrm{BW}$ on days $1,3,5,7,9$ and 11 at a dose of $1.5 \mathrm{ml} / 5 \mathrm{rats}^{[13]}$.

\subsection{Biochemical study}

Animals of all groups were anaesthetized with intraperitoneal injection of sodium pentobarbital (50 $\mathrm{mg} / \mathrm{kg}$ body weight $)^{[14]}$ after the last exposure and blood samples were drawn into sterile syringes containing EDTA from their medial orbital vein. LDH, CPK and CK-MB were estimated in all groups ${ }^{[15]}$.

\subsection{Histological study}

\section{5a. Light microscope study}

The specimens were fixed in $10 \%$ formol saline for 24 hours then dehydrated in ascending grades of alcohol before clearing in xylol. The specimens were embedded in paraffin. $5 \mu \mathrm{m}$ thick paraffin sections were obtained. The sections stained with hematoxylin and eosin (H\&E), and sirus red ${ }^{[16]}$.

\section{5b. Immunohistochemical reaction (desmin protein)}

The slides were deparaffinized in xylene, and rehydrated in graded ethanol. The endogenous peroxidase activity was blocked by incubation of sections for $30 \mathrm{~min}$ in $3 \% \mathrm{H}_{2} \mathrm{O}_{2}$. The slides were covered by 2 drops normal rabbit serum and were incubated for $30 \mathrm{~min}$ in a humid chamber. The sections were incubated with mouse antidesmin polyclonal antibody then the section was covered with biotinylated secondary anti-immunoglobulin. One to two drops of labeling antibody (streptavidin enzyme label) were added to each section ${ }^{[16]}$.

Results: The reaction is cytoplasmic. The positive reaction was indicated by brown coloration of the desmin filaments.

Positive control sections are smooth muscle.

Negative control sections were done by omitting the primary antibody.

\section{5c. Electron microscope study}

The specimens from all groups were fixed in buffered gluteraldehyde solution $(2.5 \%)$ at $\mathrm{pH} 7.4$. The specimens were dehydrated in ascending grades of ethanol then cleared in propylene oxide. The specimens were impregnated in a mixture of propylene oxide and epoxy then embedded epoxy resin. Semi thin sections were stained with toluidine blue. Then ultra thin sections ( $80 \mathrm{~nm}$, pale gold) were 
obtained from selected blocks and mounted on copper grids and examined with transmission electron microscopy at Al Mansora University ${ }^{[17]}$.

\subsection{Morphometrical study}

Leica Qwin 500 image analyzer computer system in the Image Analysis Unit in Pathology Department, Faculty of Dentistry, Cairo University was used to:

- Calculate area \% of collagen fibers,

- Optical density of immunohistochemical-stained sections for desmin protein in the myocardium of the left ventricle.

- Fiber diameter of the cardiac muscles.

The measuring frame of a standard area was equal to $7286,78 \mu \mathrm{m} 2$. For each parameter, five different non overlapping fields from each rat were examined. The measurements were done using an objective lens of magnification x 40 i.e. of total magnification x 400 .

\section{RESULTS}

\subsection{Evaluation of serum parameters}

Evaluation of serum parameters showed marked increase in LDH level in Dox- group. Vitamin E and Doxgroup showed mild increase in LDH compared to control. Liposomal-treated group showed result near to control (Figure 1)

\subsection{Histological results}

\section{$H \& E$ sections}

- Control heart ventricles sections of a and b subgroups were the same. They showed cardiomyocytes running in different directions. They appeared with acidophilic sarcoplasm and oval central vesicular nuclei with perinuclear spaces. Dox- treated group showed irregular widely separated cardiomyocytes with pyknotic nuclei and hemorrhage. Inflammatory cells infiltration and adipocytes were observed in the widened interstitium. Vitamin E and Dox-treated group showed cardiomyocytes with mild widened intercellular spaces. Some of their nuclei were vesicular, while others appeared dark. Cardiomyocytes of liposomal Dox-group nearly preserved their normal appearance with little intercellular spaces between them. They appeared with vesicular nuclei (Figures 2 and 3).

\section{Sirus red sections}

Sirus red stained-sections of heart tissue in the control rats showed few collagen fibers between cardiomyocytes. Dox-group showed abundant collagen fibers between the cardiomyocytes. Dox and vitamin E- group showed moderate increase of collagen fibers in-between cardiomyocytes. Liposomal Dox-group revealed mild increase of collagen fibers in-between cardiomyocytes (Figure 4).

\section{Semithin sections}

Toluidine blue stained-sections of the heart tissue in the control group showed cardiomyocytes with vesicular nuclei. Dox-group showed cardiomyocytes with vacuolations and areas of degenerations. Vitamin E- Dox group showed some vacuolations in the fibers. Liposomal Dox-group showed striations with vacuolations in some fibers (Figure 5).

\section{Ultrathin sections}

Ultrathin sections of the control group showed cardiomyocytes with euchromatic nuclei. Bundles of myofibrils were seen with rows of mitochondria lying between them. Myofibrils appeared with alternating dark (A) and light bands (I) bisected by Z lines. Glycogen particles were observed in between the myofibrils. Doxgroup showed cardiomyocytes with irregular fragmented nuclei. Wide interstitium was seen with excess deposition of collagen fibrils in-between the cardiomyocytes. Also, inflammatory cells with electron dense granules appeared in- between the myofibrils (Figure 6).

Vitamin E- Dox group showed cardiomyocytes with heterochromatic nuclei. Some myofibrils were well organized while others were fragmented. Disorganized mitochondria were noticed. Liposomal Dox-group showed cardiomyocytes with euchromatic nuclei. Bundles of myofibrils were seen with rows of mitochondria lying between them. $\mathrm{Z}$ lines bisected I bands. Glycogen particles were seen in-between myofibrils (Figure 7).

Ultrathin sections of the control group showed myofibrils anastomosed at the intercalated discs that had a transverse portion with adherens junction and a longitudinal portion with gap junction. Dox-group showed diorganized intercalated discs. Dox and vitamin E-group showed intercalated discs appearing partially organized. Liposomal Dox-group showed well organized intercalated discs observed in-between myofibrils (Figure 8).

\section{Immunohistochemical study}

- Immunohistochemical reaction for desmin protein showed a strong positive cytoplasmic immunoreaction which appeared mainly in the intercalated discs and cytoplasmic striations. Dox-group showed a weak positive cytoplasmic immunoreaction in numerous cardiomyocytes with disappearance of the intercalated discs and cytoplasmic striations. Dox and vitamin E-group showed moderate positive cytoplasmic immunoreaction increased in intercalated discs and cytoplasmic striations. Liposomal Dox-group showed strong positive cytoplasmic immunoreactions for desmin with well defined intercalated discs and cytoplasmic striations (Figure 9).

\section{Morphometrical study}

- Cardiac muscle fiber diameter in the different groups showed marked decrease in the Dox-group by about 2.2 
folds in comparison to the control $(p<0.001)$. On the other hand, the use of Vitamin E significantly improved cardiac muscle fiber diameter by about 1.6 folds in comparison to Dox alone. The use of liposomal Dox did not significantly affect the cardiac muscle fiber diameter in comparison to control. Interestingly, liposomal Dox -treated rats presented an increase in the cardiac muscle fiber diameter by about 2.2 folds in comparison to Dox-treated rats $(p<0.001)$ (Figure 10).

- The area percent of collagen fibers in the Dox-group increased markedly by about 6.12 folds in comparison to the control group $(p<0.001)$. The use of vitamin $\mathrm{E}$ with Dox markedly decreased collagen deposition by about 1.8 folds compared to Dox alone. Importantly, liposomal-Dox didn't induce any collagen deposition with a pattern near to control $(p<0.08)$ (Figure 11).

Statical analysis of the mean values of the optical density of immunoreactions for desmin protein in the cardiomyocytes among the different group showed marked decrease in the Dox-group by about 28.2 folds in comparison to the control group. Vitamin $\mathrm{E}$ and Dox group showed decreased optical density compared to the control group. Liposomal Dox results were near to the control group with an increase by about 27.24 folds in comparison to the Dox-group (Figure 12).

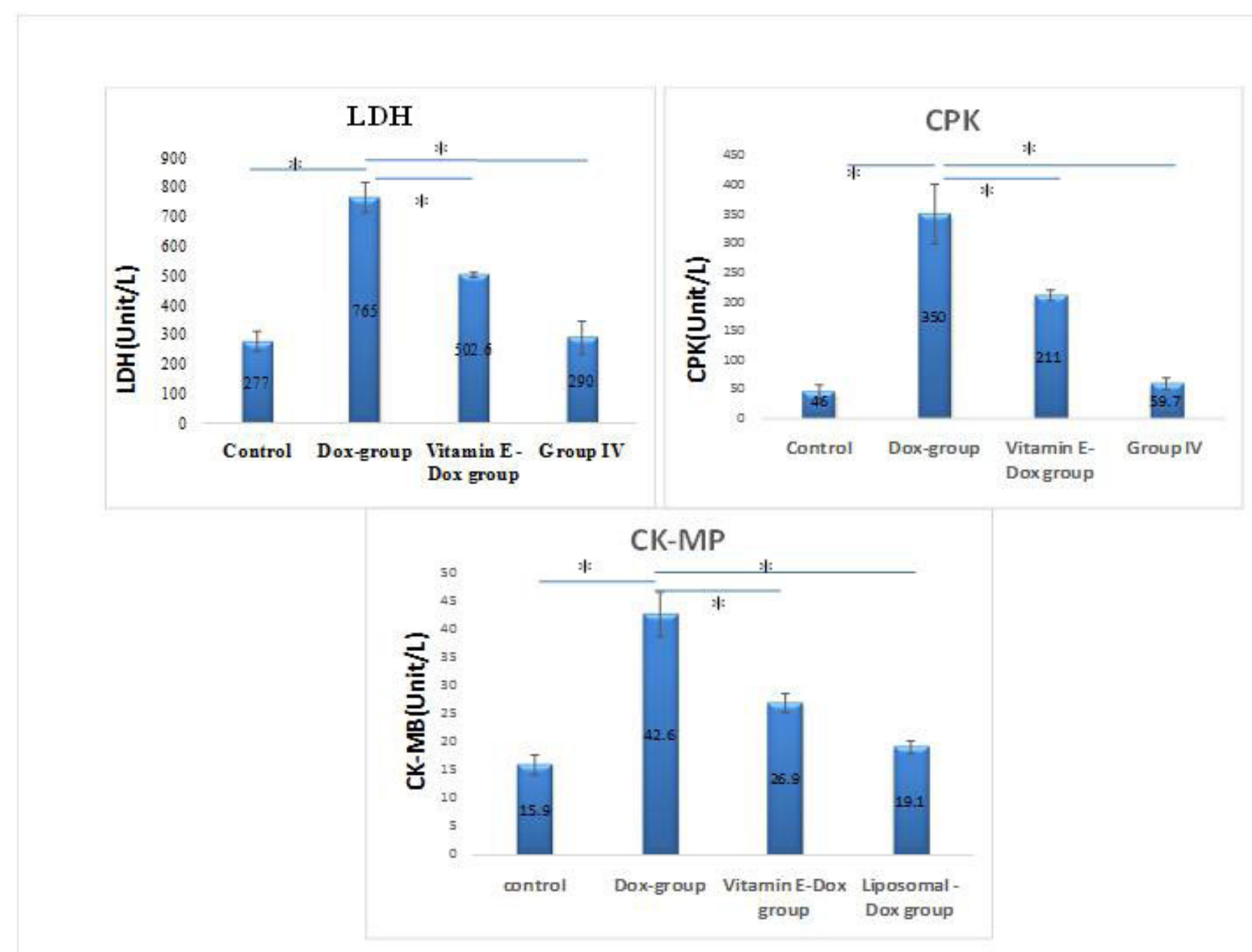

Fig. 1: The mean values of biochemical markers (LDH, CPK and CK-MP) levels in the blood of adult male albino rats. Results are expressed as mean \pm SEM $(\mathrm{n}=10) . * P$-value $<0.001$ is highly significant. 

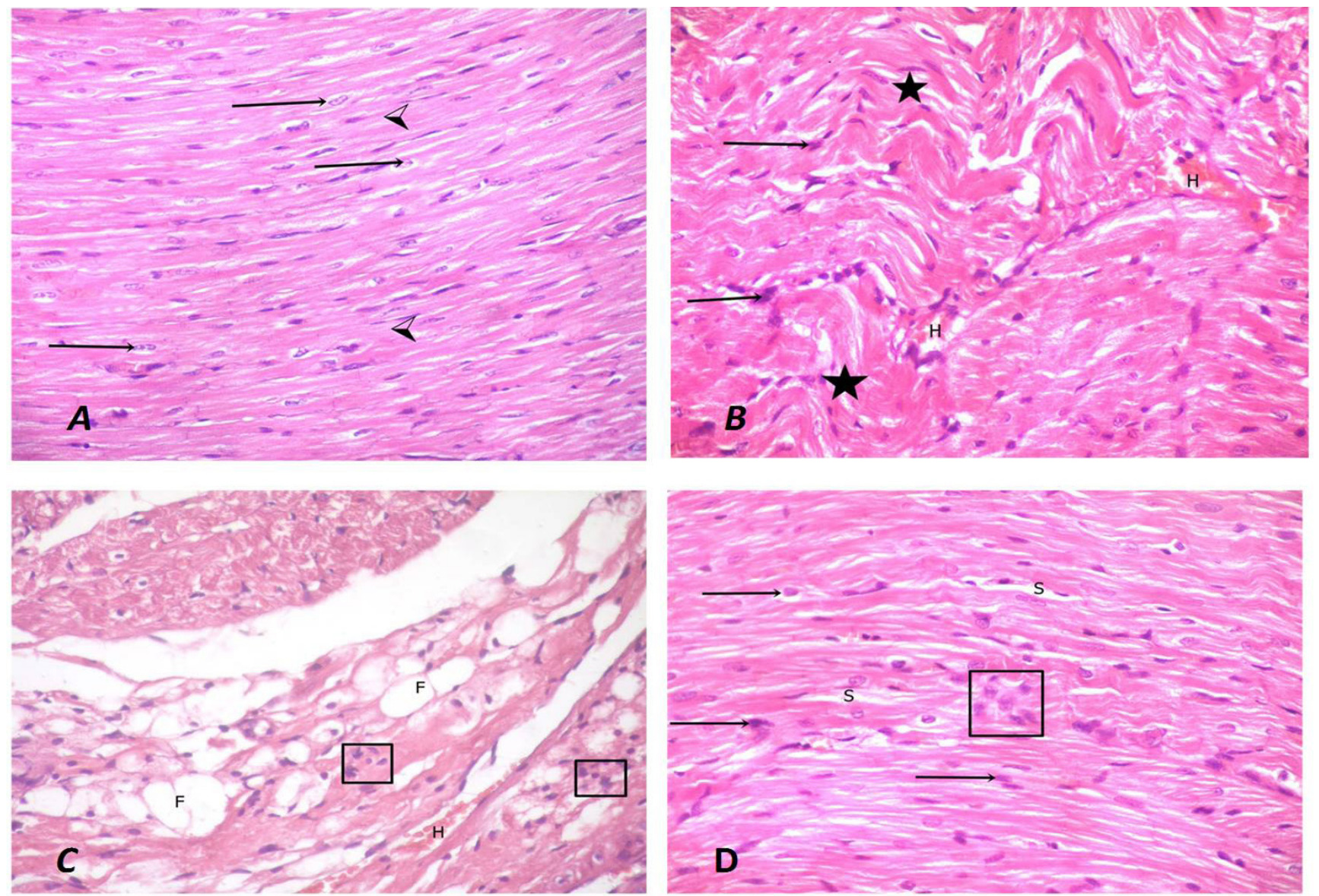

Fig. 2: (A) A photomicrograph of a control group rat heart showing cardiomyocytes with acidophilic sarcoplasm (arrow heads) and oval central bright vesicular nuclei with perinuclear spaces (arrows). (B) A photomicrograph of Dox-treated group rat heart showing irregular cardiomyocytes (stars) with pyknotic nuclei (arrows) and hemorrhage in-between them $(\mathrm{H})$. (C) A photomicrograph of Dox -treated group rat heart showing loss of normal architecture and fragmentation of cardiomyocytes with inflammatory cells infiltration (rectangle) and hemorrhage $(\mathrm{H})$ in-between them. Adipocytes are seen in the wide interstitium (F). (D) A photomicrograph of Dox-treated group rat heart showing wide intercellular space (S), pyknotic nuclei (arrows) and inflammatory cell infiltration (rectangle) (H and E X400).
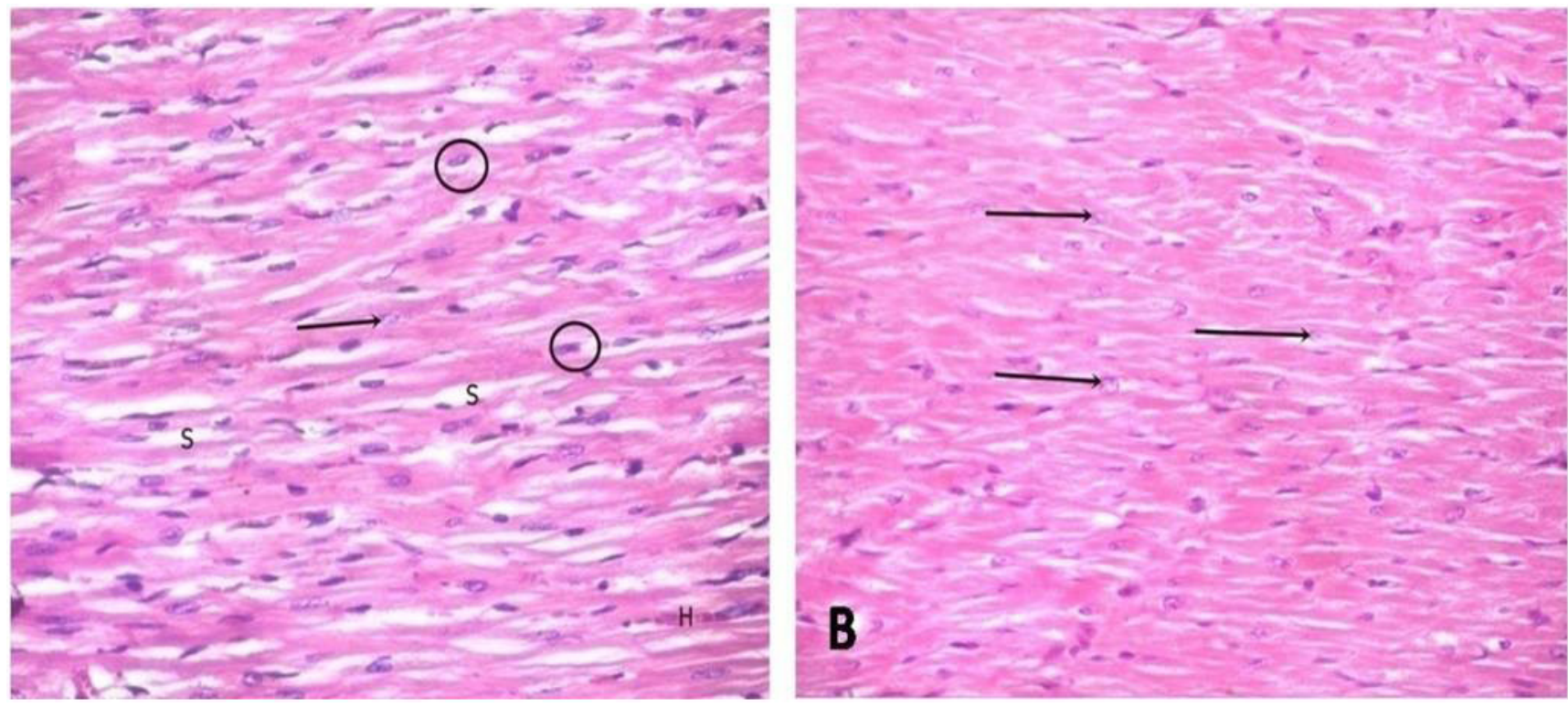

Fig. 3: (A) A photomicrograph of Dox and vitamin E-group showing cardiomyocytes with some vesicular nuclei (arrow), while others appear dark (circles) Cardiomyocytes appeared mildly separated (S). (B) A photomicrograph of liposomal Dox-treated group showing cardiomyocytes with vesicular nuclei (arrows) (H and E X400) 

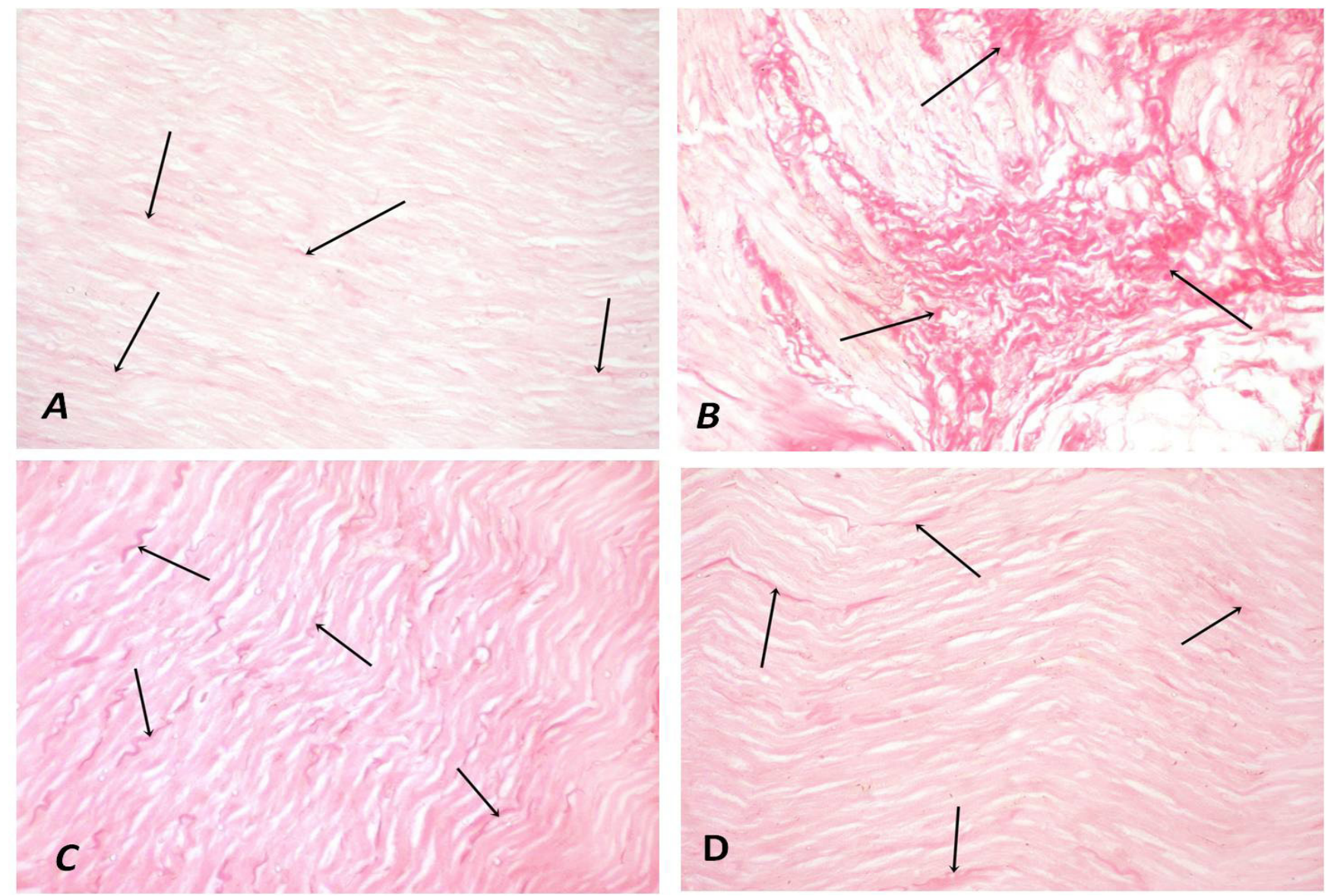

Fig. 4: ( A) Photomicrograph of a control group rat heart showing few collagen fibers (arrows) between the cardiomyocytes. (B) Photomicrograph of Dox-group showing abundant collagen fibers (arrows) in-between the cardiomyocytes. (C) Photomicrograph of Dox and vitamin E-group showing moderate increase of collagen fibers (arrows) in-between cardiomyocytes. (D) Photomicrograph of liposomal Dox-group showing less collagen fibers between cardiomyocytes (arrows) (Sirus red X400).
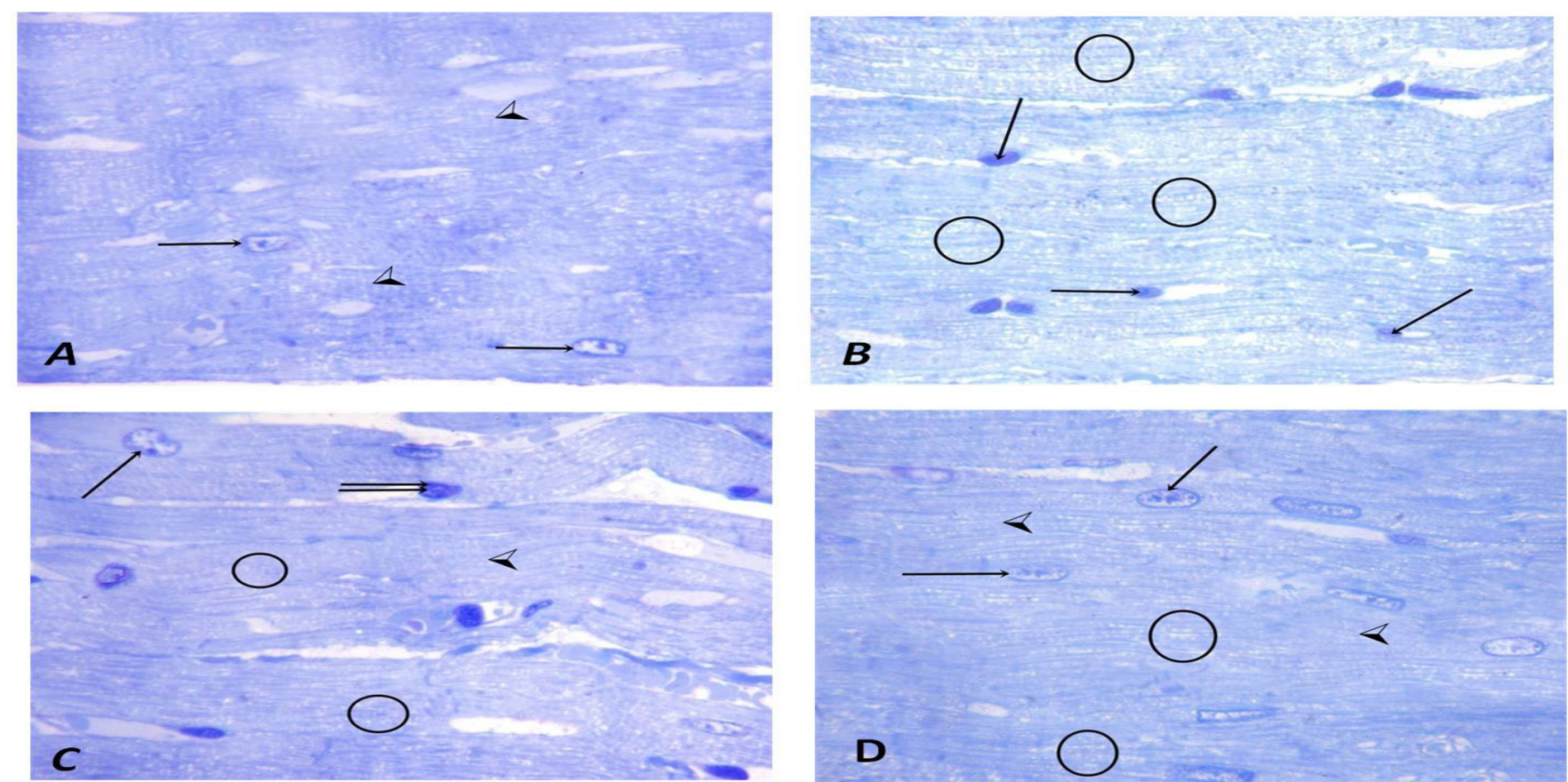

Fig. 5: (A) Photomicrograph of the control group showing cardiomyocytes with vesicular nuclei (arrows) and regular striation (arrow heads). (B) Photomicrograph of Dox-group showing darkly stained nuclei (arrows) with vacuolations (circles). (C) Photomicrograph of Dox and vitamin E-group showing striations (arrow head)are seen in most cardiac fibers, some vesicular nuclei (arrow) and others were darkly stained (double arrow).Vacuolations appear in the fibers (circles). (D) Photomicrograph of liposomal Dox-group showing striated cardiocytes (arrow heads) with showing vesicular nuclei (arrows). Some vacuolations appear in the fibers (circles) (Toluidine blue X1000). 

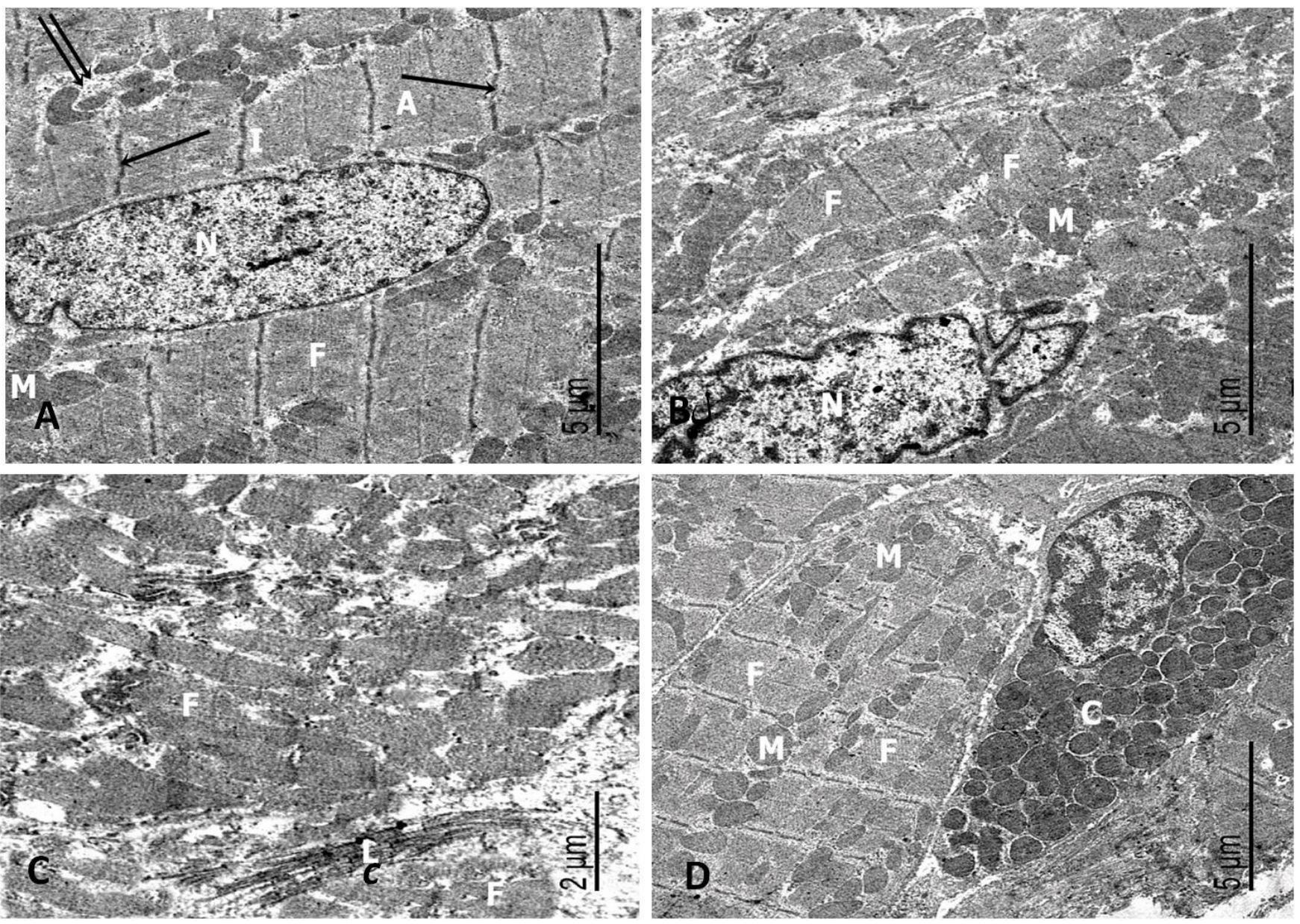

Fig. 6: Ultrathin sections of (A) the control group showing a cardiomyocyte with an euchromatic nucleus (N). Bundles of myofibrils are seen (F) with rows of mitochondria (M) lying between them. Myofibrils appear with alternating dark (A) and light bands (I). Z lines (arrows) appear bisecting I bands. Glycogen particles (double arrow) are seen in between myofibrils. (B) Dox-treated group showing irregular fragmented shaped nucleus (N). Fragmentation of some of the myofibrils (F) with enlarged mitochondria (M) is seen. (C) Ultrathin section of Dox-treated group showing fragmented myofibrils (F) and excess deposition of collagen fibrils (C). (D) Ultrathin section of Dox-treated group showing an inflammatory cell with electron dense granules (G) in-between the myofibrils (F) with enlarged mitochondria (M).
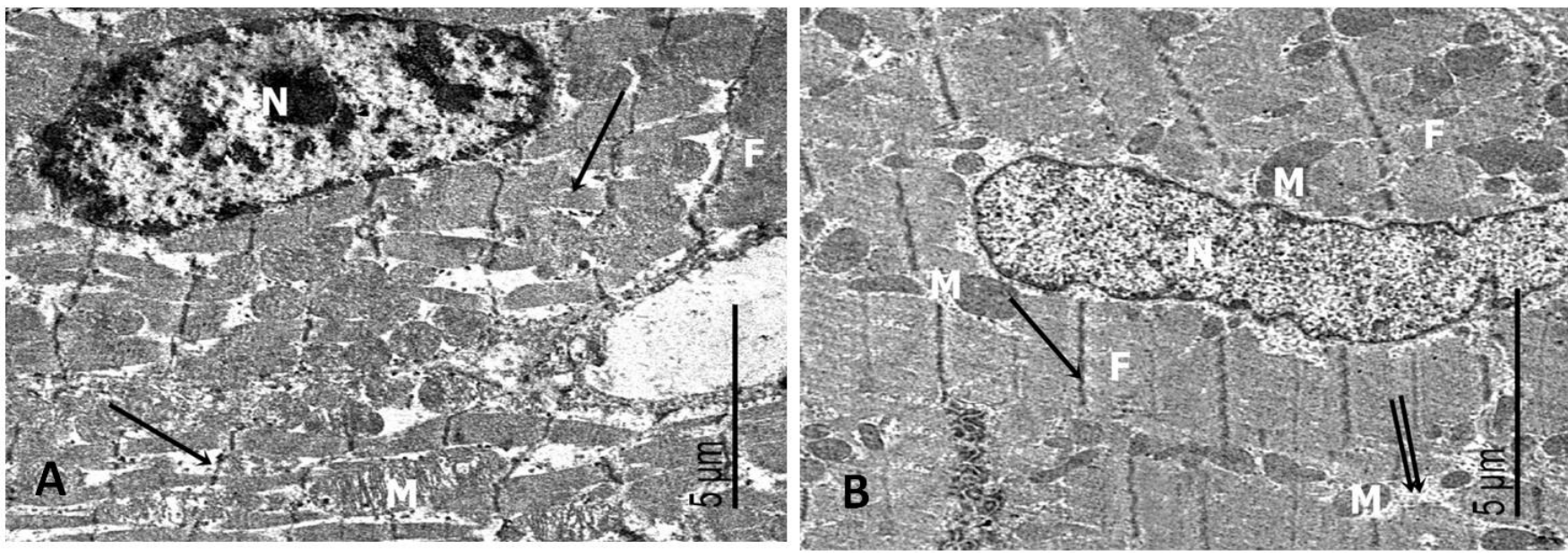

Fig. 7: Electron photomicrographs of (A) Dox and vitamin E-group showing a cardiomyocyte with a heterochromatic nucleus (N). Some myofibrils are well organized (F) while others are fragmented (arrows). Disorganized mitochondria (M) are noticed. (B) Liposomal-Dox group showing a cardiomyocyte with an euchromatic nucleus $(\mathrm{N})$. Bundles of myofibrils are seen $(\mathrm{F})$ with rows of mitochondria $(\mathrm{M})$ lying between them. Z lines (arrow) appear bisecting I bands. Glycogen particles (double arrow) are seen in-between myofibrils. 

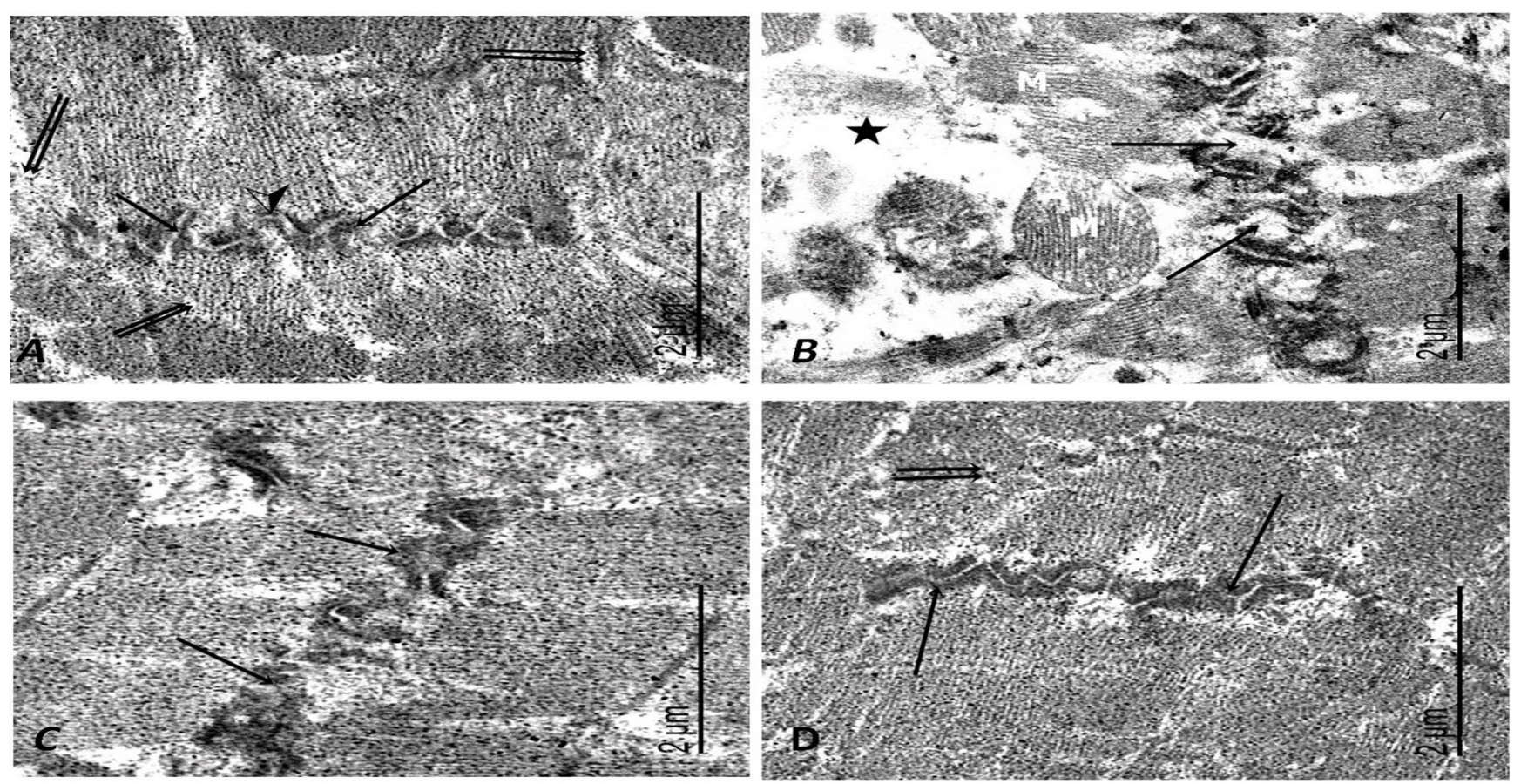

Fig. 8: Electron photomicrographs of (A) the control group showing anastomosing cardiac myofibrils at the intercalated disc that has a transverse portion with adherens junction (arrows) and a longitudinal portion with gap junction (arrow head). Glycogen particles (double arrows) are seen in-between myofibrils. (B) Dox-group showing wide area of sarcoplasmic matrix (star) in-between myofibrils. Some mitochondria have disrupted cristae and membrane (M). Disrupted intercalated disc (arrows) is also observed. (C) Dox and vitamin E-group showing intercalated disc (arrows) that appears partially organized. (D) LiposomalDox group showing well organized intercalated disc (arrows). Glycogen particles (double arrow) are observed in-between myofibrils.
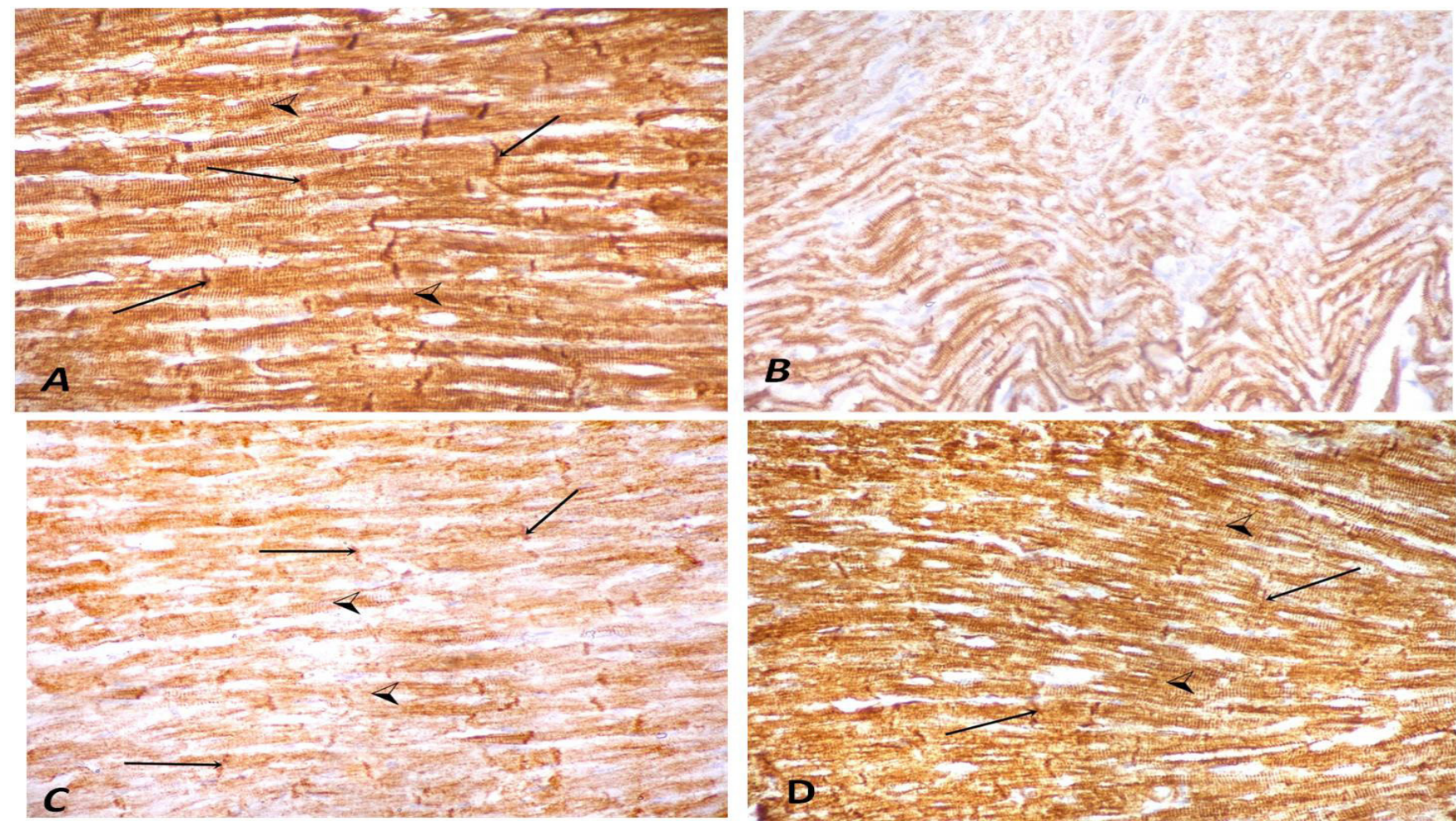

Fig. 9: (A) A photomicrograph of a control group rat heart showing strong positive cytoplasmic immunoreaction for desmin protein which appears mainly in intercalated discs (arrows) and cytoplasmic striations (arrow heads). (B) A photomicrograph of Dox-group showing weak positive cytoplasmic immunoreaction with disappearance of intercalated discs and cytoplasmic striations. (C) A photomicrograph of Dox and vitamin E-group showing moderate positive cytoplasmic immunoreaction with intercalated discs(arrows) and cytoplasmic striations (arrow heads). (D) A photomicrograph of liposomal Dox-group showing strong positive cytoplasmic immunoreaction for desmin in intercalated discs (arrows) and cytoplasmic striations (arrow heads) (Desmin immunoreaction X400). 


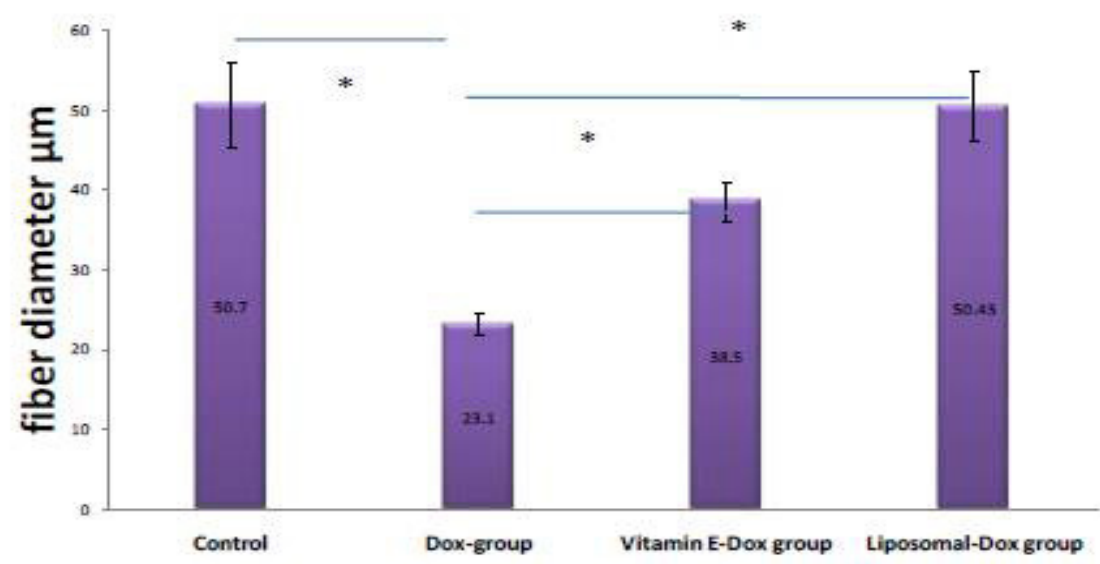

Fig. 10: The mean values of the cardiomyocytes diameter of the studied groups. Results are expressed as mean \pm SEM ( $\mathrm{n}=10)$.* $P$-value $<0.001$ is highly significant.

\section{Area percent}

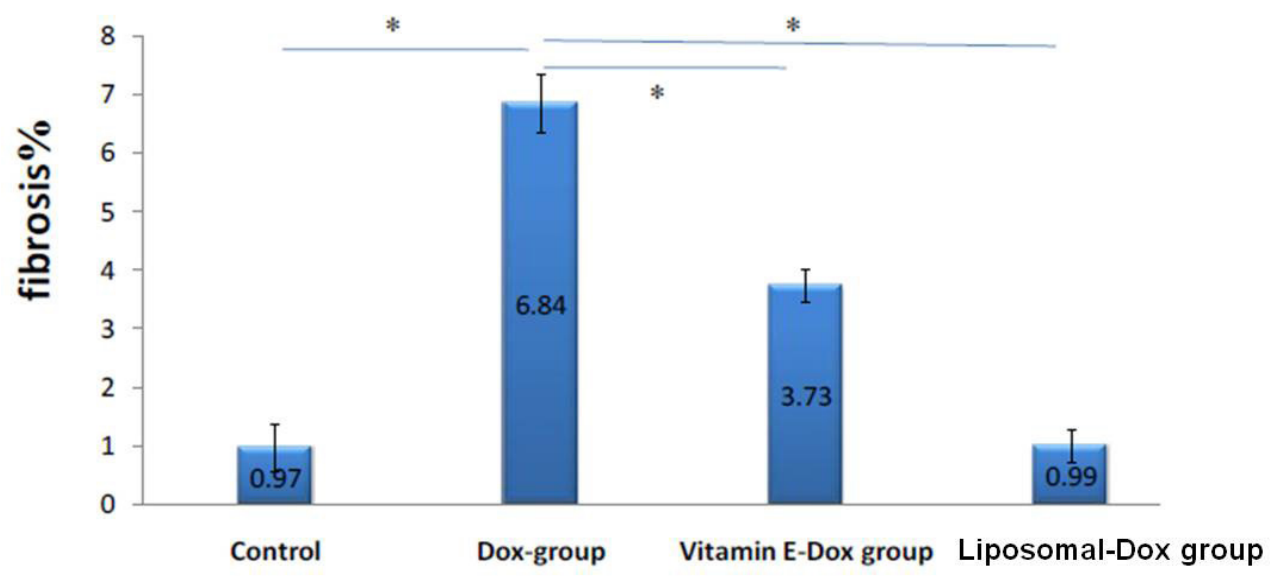

Fig. 11: The mean values of the area percent of collagen fibers between the cardiomyocytes. Results are expressed as mean \pm SEM ( $\mathrm{n}=10)$. ${ }^{*} P$-value $<0.001$ is high significant.

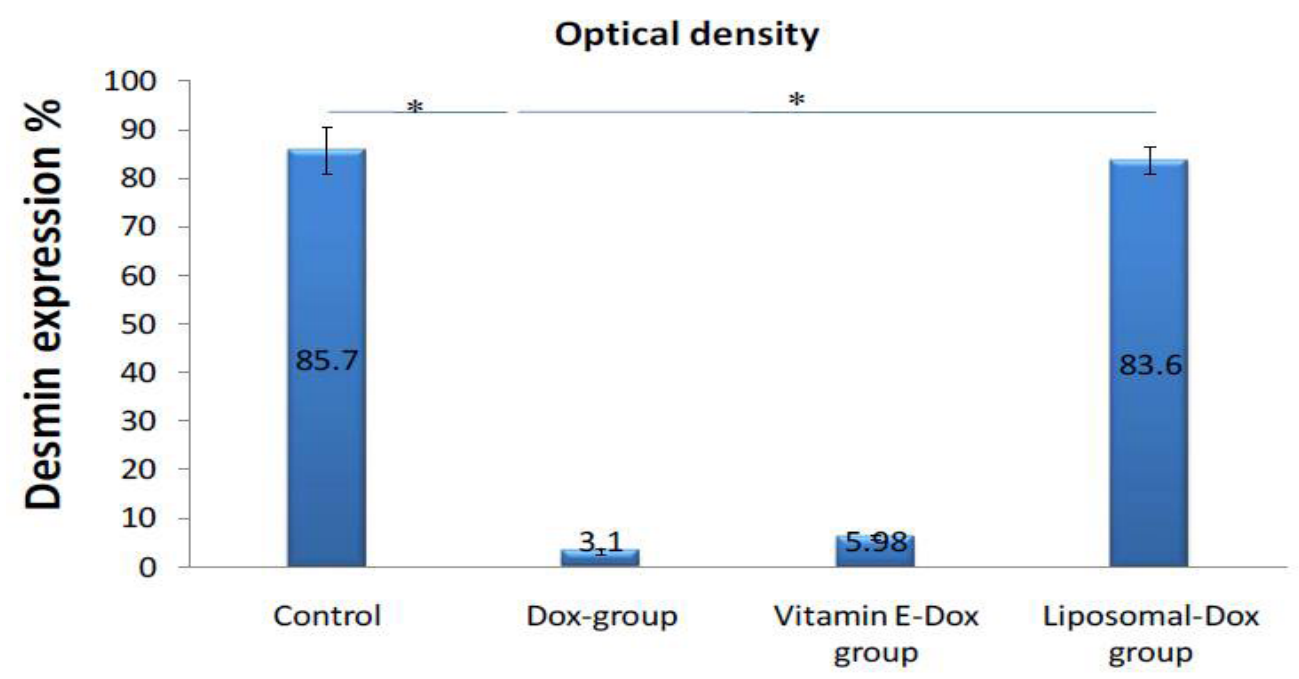

Fig. 12: The mean values of the optical density of immunoreactions for desmin protein in the cardiomyocytes among the different group. Results are expressed as mean \pm SEM $(\mathrm{n}=10){ }^{*} P$-value $<0.001$ is highly significant. 


\section{DISCUSSION}

Over the last years, cancer treatment has become more effective leading to significant improvements in survival rates. However anticancer drugs can have several possible cardiovascular side effects; in particular the development of the left ventricular dysfunction which can negatively affect patients cardiac outcome and can limit anticancer treatments $^{[18]}$

Many clinical trials were applied to attenuate Dox sideeffects without interfering with its activity on tumor cells by adding of antioxidant e.g vitamin $E$ to neutralize the free radicals and other toxic non-radicals generated by Dox ${ }^{[7]}$. Also, encapsulation of Dox by a liposomal membrane can decrease its cardiotoxicity ${ }^{[19]}$. Therefore, this study was designed to investigate the role of liposomal Dox in decreasing the histological damage and the variation of immunohistochemical expression of desmin in the ventricular heart muscle after Dox administration versus the effect of vitamin $\mathrm{E}$ administration with Dox in male wister albino rat.

All animals used in this study were males to avoid any effect of the gender on the results. Gender difference has been mentioned as one of the risk factors in the toxic effects of Dox as females have more severe cardiotoxicity with more depressed contractility than males ${ }^{[20]}$.

Microscopic examination of H\&E stained sections of Dox group revealed nuclear pyknosis with loss of striations in the ventricular cardiomyocytes. It was reported that Dox is interposed into DNA with disruption of DNA repair and generation of free radicals leadind to harmful effects on nuclear DNA and cell proteins ${ }^{[21]}$.

Microscopic examination revealed that multiple fat cells were deposited in between the cardiomyocytes. Carvalho et al. (2010) found that in a model of Dox-treated rat, long-chain-fatty acid oxidation in cardiac mitochondria is significantly decreased and shift to glucose when metabolic genes are transcriptionally suppressed which lead to fatty deposition in the cardiac tissue. This metabolic shift is induced by Dox oxidative stress and signaling ${ }^{[18]}$.

Hemorrhagic areas appeared in between cardiomyocytes in the heart of the rats treated with Dox. Attia et al. (2017) reported that vascular endothelial growth factor (VEGF) increased with Dox treatment which has many effects on endothelial cells related to vasodilation and increase permeabiliy ${ }^{[22]}$.

Toluidine blue stained sections revealed cardiomyocytes with vacuolations and areas of degeneration. These findings were in accordance with the work of Edwards and Mitry (2016) who found that Dox damages the plasma membrane of cardiomyocytes with disturbing the intracellular water and electrolytes distribution ${ }^{[23]}$.

Increase of collagen fibers in between cardiomyocytes was demonstrated in the sirus red sections and was confirmed statistically by the significant increase of the mean area percentage of collagen fibers in the heart of Dox-treated group in comparison to the control group. Also, examination of ultrathin sections of Dox-treated group revealed wide interstitium with excess deposition of collagen fibrils in between fragmented myofibrils.

These changes were explained by increasing the fibroblasts activity through the free radical stress to Dox.

Immunohistochemical stained sections showed weak positive cytoplasmic immunoreaction for desmin protein in the cardiac fibers with loss of the normal striations and intercalated discs in Dox- treated group. Decreased desmin expression in the kidneys of Dox-treated rats was also documented. It was explained by the destructive effect of Dox on the intracellular proteins including the desmin $\operatorname{protein}^{[24]}$.

Examination of the ultrathin sections of Dox-treated group revealed disrupted disorganized cardiomyocytes with irregular shaped nuclei. This can be explained by the effect of Dox in disturbing the function of topoisomerases (highly conserved enzymes that regulate DNA topology to facilitate DNA replication, transcription and other nuclear processes), resulting in double-strand DNA break ${ }^{[25]}$. It was found that Dox treatment increases the level of ceramide (lipid molecule that is involved in a variety of cellular processes including growth arrest, apoptosis, and senescence) which leads to nuclear fragmentation and cell damage ${ }^{[26]}$

Myofibrils fragmentation in this group was further proved by the morphometrical study of of the diameter of cardiac ventricular fibers. Statistical analysis of the results showed a high significant decrease in the fibers diameter. These findings were in agreement with a previous study that demonstrated decreasing in myofibrillar bundles and degradation of sarcomeric titin. Titin is a giant protein, also known as connectin that functions as a molecular spring which is responsible for the passive elasticity of muscles $^{[27]}$. The integrity of the contractile filaments is brought into disrepute or danger on exposure to Dox in the heart with loss of sarcomeres and decreases contractile function leading to subsequent heart failure ${ }^{[28]}$.

Cardiac fibers degeneration in Dox- treated group was accompanied with a significant statistical increase in CPK, LDH and CK-MB of Dox- treated group in comparison to the control group. Similar increase in the levels of cardiac markers in the serum of Dox-treated rats was also reported ${ }^{[29]}$ and was explained by the damage of the cardiomyocytes and releasing of their enzymes into the blood $^{[30]}$.

Variable sized mitochondria with ruptured cristae were observed in-between the fragmented myofibrils of Doxtreated group. Mitochondrial size variability was explained by continuous replacement of damaged mitochondria by newly synthesized ones in order to sustain the constant need for ATPs ${ }^{[31]}$.

In addition, Dox binds the abundant phospholipid 
cardiolipin located in the inner mitochondrial membrane, which leads to mitochondrial accumulation of the drug. This would disrupt the electron transport chain and increases ROS production ${ }^{[32]}$. It can interact directly with iron to form reactive anthracycline-iron complexes resulting in an iron cycling between $\mathrm{Fe} 3+$ and $\mathrm{Fe} 2+$ associated with ROS production. Therefore, the intramitochondrial accumulation of iron increases with more ROS production and mitochondrial damage ${ }^{[33]}$.

Inflammatory cells with electron dense granules appeared in between myofibrils in Dox-treated group. Chen et al. (2002) reported that cardiotoxic injury induced by Dox may result through inflammatory cells activation, which discharge myleoperoxidase and IL-1 $7^{[34]}$.

H\&E-stained sections of Dox and vitamin E-treated group revealed improvement in the histological structure of the ventricular cardiomyocytes. They were mildly separated and contained some hemorrhagic areas. Some of their nuclei were vesicular, while others appeared dark. Toluidine blue sections revealed some vacuolations in the fibers. This improvement in the ventricular fibers was confirmed by a significant statistical decrease in CPK, LDH and CK-MB of Dox and vitamin E- treated group in comparison to Dox-treated group. Bialostosky (2002) explained this improvement by the role of vitamin $\mathrm{E}$ in the protection of the cell membranes at an early stage of free radicals attack ${ }^{[35]}$.

Vitamin E can neutralize the free radicals resulted from Dox exposure, decrease their harmful effect on the cardiomyocytes which leads to improve cardiac function ${ }^{[7]}$.

Sirus red stained sections revealed moderate increase of collagen fibers in between cardiomyocytes of Dox and vitamin E-treated group in comparison to Dox-treated group. It was mentioned that the mechanism by which vitamin $\mathrm{E}$ decreases the extracellular matrix fibrosis is to inhibit signaling pathways such as modulating the synthesis of MMPs and the release of pro-inflammatory cytokines which is the most important mediators in the extracellular matrix fibrosis. Moreover, vitamin E inhibits the activity of ROS-generating systems such as iNOS or NADPH oxidase which increase fibrosis ${ }^{[36]}$.

Desmin immunohistochemical-stained sections of Dox and vitamin $\mathrm{E}$ treated group revealed a moderate positive cytoplasmic immunoreaction in intercalated discs and cytoplasmic striations. Desmin was demonstrated to be a major target of oxidation in the cells which leads to desmin aggregation and damage with Dox treatment. Vitamin E decreases the harmful effect of Dox on desmin protein through its antioxidant action ${ }^{[37]}$.

Disorganized mitochondria were noticed in the ultrathin sections of Dox and vitamin E-treated group. It was suggested that although vitamin $E$ enriches the cardiac mitochondrial membranes with alpha-tocopherol and diminishes the free radicals, it isn't sufficient for complete and perfect protection from Dox harmful effects ${ }^{[38]}$. These authors concluded either (1)tocopherol enrichment is not sufficient to protect cardiac mitochondrial membranes from Dox toxicity or (2) oxidative stress alone is not responsible for the persistent mitochondrial cardiomyopathy caused by long-term.

Examination of H\&E-stained sections of the left ventricular myocardium of liposomal Dox-treated group revealed cardiomyocytes nearly preserved their normal appearance with little intercellular spaces in-between muscle fibers. Cardiomyocytes appeared with vesicular nuclei. Toluidine blue stained sections showed striations and some vacuolatins in the fibers. Sirus red stained sections revealed mild increase of collagen fibers in between cardiomyocytes. This was confirmed by ultrathin sections examination of the left ventricular myocardium which revealed cardiomyocytes with euchromatic nuclei and different organelles near to normal structure. Also, this group showed nearly normal serum level of CPK, LDH and CK-MB which confirmed the histological results.

Liposomal Dox accumulates preferentially in the tumor tissue through the discontinuous and disorganized vasculture. Also, the impaired lymphatics of the tumor increase the retention time of Dox in the tumor tissue, which results in higher concentrations than in other tissues. These properties increase liposomal Dox efficacy on the tumor cells with need to little dose in the clinical practice with few side effects on the heart ${ }^{[39]}$.

This formulation of Dox reduces drug uptake by the reticulo-endothelial system due to entrapment of it inside the nanoparticle. These features result in pharmacokinetics with dramatically extended circulation time and a reduced volume of distribution, as compared to those of free Dox ${ }^{[40]}$. It was also observed that cardiotoxicity which is a major adverse effect of free Dox is significantly reduced in the patients treated with liposomal Dox ${ }^{[41]}$.

The advantages of the therapeutic liposomes can be summarized as: liposomes increase efficacy and therapeutic index of the drug by increasing the drug stability and decreasing its toxicity via encapsulation. They are biocompatible, completely biodegradable, nontoxic, flexible and nonimmunogenic for systemic and nonsystemic administrations. Also, they are flexible to couple with site-specific ligands to achieve active targeting ${ }^{[42]}$.

The ultra-small size of liposomes is notably smaller than the diameter of many human cells.

A pilot clinical trial study on 15 cancer patients in which liposomal Dox was compared with the free Dox was reported. The researchers concluded that liposomal Dox has shown the ability to clinically reduce cardiotoxicity, a side effect of free Dox treatment, because encapsulated Dox is not bioavailable at cardiac muscle cells and the myocardium ${ }^{[43]}$.

Some trials demonstrated that liposomal Dox reduced cardiotoxicity and had a similar antitumor efficacy compared with conventional anthracycline ${ }^{[44]}$. Additionally, it was 
shown that liposomal Dox did not increase cardiotoxicity compared with anthracycline-free chemotherapy ${ }^{[45]}$, whereas other trials indicated that liposomal Dox was more effective than conventional anthracyclines with a similar cardiotoxicity ${ }^{[46]}$

In conclusion, Dox had serious harmful effects on the heart of adult Wister male albino rats. Dox and vitamin E-treated group showed improvement in the structure of cardiac myocytes. Liposomal Dox-treated group showed histological and biochemical parameters near to the control group.

From the results of this study, we recommend to supplement Dox-treated patients with vitamin E as an antioxidant to their treatment regimen to minimize any possible complications and the harmful effects of Dox free radicals production.

Furthermore, using liposomal-Dox as a new drug trend-if available- for treatment to provide a strong hope to cancer patients for treatment without or with minimal cardiac side effects.

\section{CONFLICTS OF INTEREST}

The authors have no conflicts of interest to declare.

\section{REFERENCES}

1. Yu J, Wang $\mathrm{C}$, Kong $\mathrm{Q}, \mathrm{Wu} \mathrm{X}, \mathrm{Lu} \mathrm{JJ}$, Chen $\mathrm{X}$. Recent progress in doxorubicin-induced cardiotoxicity and protective potential of natural products. Phytomedicine. 2018; 40:125-139.

2. Šimůnek T, Štěrba M, Popelová O, Adamcová M, Hrdina R, Gerš V. Anthracycline-induced cardiotoxicity. Overview of studies examining the roles of oxidative stress and free cellular iron. Institute of Pharmacology Polish Academy of Sciences, Pharmacological Reports. 2009; 1:154-171.

3. Berthiaume JM, Wallace KB. Adriamycin-induced oxidative mitochondrial cardiotoxicity. Cell Biol Toxicol. 2007; 23:15-25.

4. Ichikawa $\mathrm{Y}$, Ghanefar $\mathrm{M}$, Bayeva $\mathrm{M}$, $\mathrm{Wu}$ R, Khechaduri A, Sathyamangla V, Prasad N,Mutharasan K, Naik $\mathrm{T} J$, Ardehali $H$. Cardiotoxicity of doxorubicin is mediated through mitochondrial iron accumulation. J Clin Invest. 2014; 2:617-630.

5. Hu Z, , Jiang X, Charles F, Albright, Graciani N, Yue E, Zhang M, Zhang SY, Bruckner R, Diamond $\mathrm{M}$, Dowling R, Rafalski $\mathrm{M}$ et al. Discovery of matrix metalloproteases selective and activated peptide-doxorubicin prodrugs as anti-tumor agents. Bioorganic and Medicinal Chemistry Letters. 2010; 3:853-856.

6. Al-Hadi HA, Keith A Fox KA. Cardiac Markers in the Early Diagnosis and Management of Patients with Acute Coronary Syndrome. Sultan Qaboos Univ Med J. 2009; 3:231-246.

7. Ojha S, Al Taee H,1 Goyal S, Umesh B, Mahajan, Chandrgouda R, Patil DS, Arya, Rajesh M. Cardioprotective potentials of plant-derived small molecules against doxorubicin associated cardiotoxicity. Oxidative Medicine and Cellular Longevity. 2016; 5724973.

8. Sindhi V, Gupta V, Sharma K., Bhatnagar S, Kumari R, Dhaka N. Potential applications of antioxidants-a review. JPR. 2013; 7: 828-835.

9. Baetke S C, Kiessling F. Applications of nanoparticles for diagnosis and therapy of cancer. British Journal of Radiology. 2015; 88(1054), 20150207.

10. Barenholz Y. Doxil@ - The first FDA-approved nano-drug. Lessons learned. Journal of Controlled Release. 2012; 160(2): 117-134.

11. Platel D, Bonoron-Adèle S, Dix RK, Robert J. Preclinical evaluation of the cardiac toxicity of HMR-1826, a novel prodrug of doxorubicin. British Journal of Cancer. 1999; 81(1):24-27.

12. Kulkarni JM, Swamy AV. Cardioprotective effect of gallic acid against doxorubicin-induced myocardial toxicity in albino rats.Indian $\mathrm{J}$ health sciences. 2015; 8(1):28-35.

13. Treat LH, McDannold N, Zhang Y, Vykhodtseva $\mathrm{N}$, Hynynen K. Improved anti-tumor effect of liposomal doxorubicin after targeted bloodbrain barrier disruption by MRI-guided focused ultrasound in rat glioma. Ultrasound Med Biol. 2012; 38(10): 1716-1725.

14. Zatroch KK, Knight CG, Reimer JN, Pang DS. Refinement of intraperitoneal injection of sodium pentobarbital for euthanasia in laboratory rats (Rattus norvegicus). BMC Vet Res. 2016; 13- 60.

15. Parasuraman S, Raveendran R, Kesavan R. Blood sample collection in small laboratory animals. J Pharmacol Pharmacother. 2010; 2: 87-93.

16. Bancroft J, Gamble A. A Theory and Practice of Histological Techniques. 6th ed. Chuchil Livingstone, New York, London. 2008; pp: $165-175$.

17. Singh D. Principle and Technique in Histology, Microscopy and Photography. 1st ed. CBS Publishers and Distributers. New Delhy and Bangalore (India). 2003; pp. 679-669.

18. Carvalho RA, Sousa RP , Cadete VJ, Lopaschuk GD, Palmeira CM, Bjork JA et al. Metabolic remodeling associated with subchronic doxorubicin 
cardiomyopathy. Toxicology. 2010; 270: 92-98.

19. Gabizon A, , Shmeeda H, Grenader T. Pharmacological basis of pegylated liposomal doxorubicin. Impact on cancer therapy. European Journal of Pharmaceutical Sciences. 2012; 4:388 398.

20. Puma N, Ruggiero A, Ridola $\mathrm{V}$ et al: Anthracycline-related cardiotoxicity: risk factors and therapeutic options in childhood cancers. Signa Vitae ; 2008: 3(1), 30 - 34.

21. Adwas AA, Elkhoely AA, Kabel AM, AbdelRahman MN, Eissa AA. Ameliorative potential of different doses of indol-3-carbinol on doxorubicininduced cardiotoxicity in mice. Journal of Cancer Research and Treatment. 2016;2: 26-31.

22. Attia GM, Elmansy RA, Algaidi SA. Silymarin decreases the expression of VEGF-A, iNOS and caspase-3 and preserves the ultrastructure of cardiac cells in doxorubicin induced cardiotoxicity in rats: a possible protective role. Int J Clin Exp Med. 2017; 2:4158-4173.

23. Edwards JG and Mitry MA: Doxorubicin induced heart failure: Phenotype and molecular mechanisms. Int J Cardiol Heart Vasc.; 2016:10, $17-24$.

24. Wang Z, WansenSuna J. Effects of asiaticoside on levels of podocyte cytoskeletal proteins and renal slit diaphragm proteins in adriamycin-induced rat nephropathy. Life Sciences. 2013; 8: 352-358.

25. Pommier Y, Leo E, Zhang H, Marchand C: DNA topoisomerases and their poisoning by anticancer and antibacterial drugs. Chem Biol. 2010; $17: 421-433$.

26. Chen Q, Denard B, Huang H, Ye J. Epigenetic silencing of antiviral genes renders clones of Huh7 cells permissive for hepatitis $\mathrm{C}$ virus replication. J Virol. 2013; 1:659-665.

27. Lim CC, Zuppinger C, Guo X, Kuster GM, Helmes M, Eppenberger HM, Suter TM, Liao R, Sawyer DB. Anthracyclines induce calpain-dependent titin proteolysis and necrosis in cardiomyocytes. J Biol Chem. 2004; 9: 8290-8299.

28. Arif IS, Hooper CL, Greco F, Williams AC, Boateng SY. Increasing doxorubicin activity against breast cancer cells using PPAR $\gamma$-ligands and by exploiting circadian rhythms. $\mathrm{Br} \mathrm{J}$ Pharmacol. 2013; 5: 1178-1188.

29. Somashekar B, Rai SS, Kp SG. Cardioprotective effects of ethanolic leaf extract of ipomoea batatas on doxorubicin induced cardiotoxicity in rats. Asian J Pharm Clin Res. 2015; 2:444-450.

30. Singh P, Sharma R, McElhanon K, Allen CD,
Megyesi JK, Beneš H, Singh SP. Sulforaphane protects the heart from doxorubicin-induced toxicity .Free Radic Biol Med. 2015; 86:90-101.

31. Gorini S, Angelis A, Berrino L, Malara N, Rosano G, Ferraro E. Chemotherapeutic Drugs and Mitochondrial Dysfunction. Focus on Doxorubicin, Trastuzumab, and Sunitinib. Oxidative Medicine and Cellular Longevity. 2018; 2018: 7582730.

32. Aryal B, Rao VA. Deficiency in cardiolipin reduces doxorubicin-induced oxidative stress and mitochondrial damage in human b-lymphocytes. PLoS One. 2016; 7:0158376.

33. Chen HW, Chien CT, Yu SL, Lee YT, Chen WJ. "Cyclosporine A regulates oxidative stress-induced apoptosis in cardiomyocytes: mechanisms via ROS generation, iNOS and Hsp70”.Br. J. Pharmacol. 2002; 137:771-781.

34. Bialostosky K. Dietary intake of macronutrients, micronutrients and other dietary constituents. Vital and Health Statistics. 2002; 245:1-158.

35. Alcalá M, Sánchez-Vera I, Sevillano J, Herrero L, Serra D, Ramos MP, Viana M. Vitamin E reduces adipose tissue fibrosis, inflammation, and oxidative stress and improves metabolic profile in obesity. Obesity (Silver Spring). (2015)23(8):1598-606.

36. Cabet E, Batonnet-Pichon S, Delort F, Gausserès B, Vicart P, Lilienbaum A. Antioxidant treatment and induction of autophagy cooperate to reduce desmin aggregation in a cellular model of desminopathy. PLoS One. 2015; 9: 0137009.

37. Berthiaume JM, Wallace KB. Adriamycin-induced oxidative mitochondrial cardiotoxicity. Cell Biol Toxicol. 2007; 23:15-25.

38. Petros RA, Desimone JM. Strategies in the design of nanoparticles for therapeutic applications. Nature Reviews Drug Discovery. 2010; 9:615-627.

39. Blanco E, Shen H, Ferrari M. Principles of nanoparticle design for overcoming biological barriers to drug delivery. Nat Biotechnol. 2015; 9:941-951.

40. Ngan YH, Gupta M. A comparison between liposomal and nonliposomal formulations of doxorubicin in the treatment of cancer. An updated review. Archives of pharmacy Spractice. 2016; 1:1-13

41. Yokoi K, Chan D, Kojic M, Milosevic M, Engler D, Matsunam R, Tanei T, Saito Y, Ferrari M, Ziemys A. Liposomal doxorubicin extravasation controlled by phenotype-specific transport properties of tumor microenvironment and vascular barrier. J Control Release. 2015; 217:293-299. 
42. Anwekar H, Patel S, Singhai A. Liposome- as drug carriers. International journal of pharmacy and life sciences. 2011; 7: 945-951.

43. Batist G: Cardiac safety of liposomal anthracyclines. Cardiovasc. Toxicol. 2007; 7:72-74.

44. Harris L, Batist G, Belt R, Rovira D, Navari R, Azarnia N, Welles L, Winer E. Liposomeencapsulated doxorubicin compared with conventional doxorubicin in a randomized multicenter trial as first-line therapy of metastatic breast carcinoma. Cancer. 2002; 1:25-36.

45. Sparano JA, Makhson AN, Semiglazov VF,
Tjulandin SA, Balashova OI, Bondarenko $\mathrm{IN}$, et al. Pegylated liposomal doxorubicin plus docetaxel significantly improves time to progression without additive cardiotoxicity compared with docetaxel monotherapy in patients with advanced breast cancer previously treated with neoadjuvant-adjuvant anthracycline therapy. J Clin Oncol. 2009; 27:4522-4529.

46. Chan S, Davidson N, Juozaityte E, Erdkamp F, Pluzanska A, Azarnia N, et al. Phase III trial of liposomal doxorubicin and cyclophosphamide compared with epirubicin and cyclophosphamide as first-line therapy for metastatic breast cancer. Ann Oncol. 2004; 15:1527-1534. 
الملخص العربى

\section{دراسة مقارنة لتأثير الدوكسوروبيسين مع فيتامين هـ مقابل الدوكسوروبيسين الليبوزومى على التغييرات الههيتولوجية و الهستو كيميائية التى بسببها الاكسوربوسين فى البطين الأيسر فى ذكور الجرذان البيضاء البالغة}

فادية خالد علي عبده، فايزة السيد احم، محمد عبد الرحمن غنيم شاهين، سمر عبد العزيز مصطفى يوسف قسم الهستولوجيا ـ كلية الطب - جامعة الزقازيق

الخلفية والهدف: استخدام الدوكسوروبيسين (Dox) في علاج أشكال مختلفة من الأورام محدود بسبب سميتة علي القلب. تهدف هذه الدر اسة لمقارنة إمكانية حماية بنية القلب (التركيب النسيجى للبطين الايسر) بإضافة فيتامين ه مع الدوكسوروبيسين مقابل الدكسوريبوسين الليبوزومى. المواد والطرق: خمسون من ذكور جرذان ويستر البيضاء (220-180 جم)، قسمت إلى مجموعات ضابطة (1) و مجمو عة الدكسوريبو سين (2) و مجمو عة الدكسوريبوسين مع فيتامين ه (3) ومجمو عة الدكسوريبوسين الليبوزومى(4). المجمو عات 2، 3 ، 4 تم إعطاءو ها الدكسوريبوسين و و الدكسوريبوسين الليبوزومى (3 مجم / كجم) في أيام 1 و 3 و 5 و 7 و 9 و 11. و أعطى فيتامين ه إلى المجموعة 3 (100مجم/كجم) يوميا مصاحبا للاكسورييوسين. و في اليوم الثانى عشر ، جمعت عينات الدم ، ثم تم تشريح البطين الايسر لتحضير عينات للار اسة بالمجهرين الضوئى والإلكترونى. النتائج: أظهرت مجمو عة الدكسوريبوسين زيادة ملحوظة فى مستوى انزيمات القلب (CPK) ، LHD و CK-MB) مقارنة بالمجمو عة الضابطة بينما أظهرت مجمو عتى فيتامين هو الدكسوريبوسين الليبوزومى انخفاضًا مقارنة بمجمو عة الدكسوريبوسين. وكان الانخفاض الأقصى في مجموعة الدكسوريبوسين الليبوزومى مع قيم قريبة من المجموعة الضابطة. وأظهر فحص المجهر الضوئي لعينات البطين الايسر لمجموعة الدكسوريبوسين علي خلايا عضلة بطين القلب منفصلة و احتوت على أنوية داكنة وشو هدت بينها مناطق نزفية، ووجدت خلايا التهابية و خلايا دهنية بين الألياف العضلية. و أظهرت مجموعة الدكسوريبوسين ميتوكوندريا متغيرّة الحجم مع أعراف ممزقة بين الليفيات العضلية المفتتة. كما أظهر فحص المجهرين الضوئى و الإلكتروني لعينات البطين فى مجمو عتى الدكسوريبوسين مع فيتامين ه و الدكسوريبوسين الليبوزومى تغيير ات طفيفة خصوصا في مجموعة الدكسوريبوسين الليبوزومى التي بدت قريبة إلى الطبيعي. وقد انخفض قطر ألياف البطين الأيسر مجموعة الدكسوريبوسين مقارنة بالمجموعة الضابطة وظهر القطر تقريبا طبيعيا في مجموعة الدكسوريبوسين الليبوزومى. و قد زادت النسبة المئوية للألياف الكولاجينية فى مجموعة الدكسوريبوسين، بينما قلت الكثافة الضوئية للتعبير المناعي لبروتين الدسمين فى مجموعة الدكسوريبوسين مقارنة بالمجمو عة الضابطة و مجمو عة الدكسوريبوسين الليبوزومى التى كانت متشابهة. الخلاصة: التغيير ات الهستولوجية التي بسبيها الدكسوريبوسين فى بطين الجرذان تضاءلت من خلال تناول فيتامين ه مصاحبا له. و كان الدكسوريبوسين الليبوزومى-فقطـ أكثر فعالية في الحد من هذه التغيرات، وبالتالي، فإنه يمكن اعتباره هدفا اكلينيكيا ناجحا لتقليل الاثار السمية المرتبطة الدكسوريبوسين علي القلب. 